Original Research Paper

\title{
Struktur Vegetasi Mangrove Alami dan Rehabilitasi Pesisir Selatan Pulau Lombok
}

\author{
Laily Hunawatun Sani ${ }^{1}$, Dining Aidil Candri ${ }^{2 *}$, Hilman Ahyadi ${ }^{3}$, Baiq Farista ${ }^{4}$ \\ ${ }^{1,2,3,4}$ Program Studi Biologi, Fakultas Matematika dan Ilmu Pengetahuan Alam, Universitas Mataram, Indonesia
}

\begin{abstract}
Riwayat artikel
Received : 18 September 2019

Revised : 27 September 2019

Accepted : 7 Oktober 2019

Published : 5 November 2019

*Corresponding Author:

Dining Aidil Candri

Program Studi Biologi,

Fakultas Matematika dan Ilmu

Pengetahuan Alam, Universitas

Mataram, Mataram, Indonesia

Email: aidilch@unram.ac.id
\end{abstract}

Abstrak: Rehabilitasi mangrove merupakan salah satu upaya yang dilakukan untuk mengurangi laju kerusakan hutan mangrove di Indonesia salah satunya di kawasan Teluk Gerupuk. Penelitian ini bertujuan untuk mengetahui kondisi mangrove hasil rehabilitasi di Teluk Gerupuk dengan mebandingkan struktur vegetasi mangrove di kawasan tersebut dengan ekosistem mangrove alami. Pelaksanaan penelitian dilakukan pada bulan April-Juni 2019 di dua kawasan hutan mangrove di pesisir selatan pulau Lombok yaitu hutan mangrove alami desa Pemongkong dan hutan mangrove rehabilitasi Teluk Gerupuk. Pengambilan data dilakukan dengan menggunakan metode transek berpetak dengan ukuran petak $10 \times 10 \mathrm{~m}$ untuk tipe pohon, sub petak $5 \times 5 \mathrm{~m}$ untuk tipe pancang, dan petak semai berukuran $2 \times 2 \mathrm{~m}$. Terdapat 11 spesies mangrove ditemukan di dalam plot penelitian dengan persebaran spesies yaitu 8 spaesies ditemukan di hutan mangrove alami Pemongkong dan hanya 7 spesies ditemukan di hutan mangrove rehabilitasi Gerupuk. Spesies mangrove yang dimaksud termasuk ke dalam 4 famili yaitu Avicenniaceae (Avicennia alba, A. marina, A. lanata), Rhizophoraceae (Ceriops decandra, C. tagal, Rhizophora apiculata, $R$. mucronata, $R$. stylosa), Rubiaceae (Scyphiphora hydrophyllaceae) dan Sonneratiaceae (Sonneratia alba, S. casiolaris). Struktur vegetasi kedua ekosistem sangat berbeda terlihat pada vegetasi penyusunnya. Hutan mangrove alami Pemongkong didominasi oleh jenis Sonneratia alba dan Avicennia alba yang memiliki Indeks nilai penting (INP) untuk tipe pohon dan pancang dengan nilai masing-masing 132,37 dan 141,52, sedangkan hutan mangrove rehabilitasi didapatkan INP tertinggi pada tipe pohon dan pancang yaitu jenis $R$. apiculata dan $R$. stylosa dengan INP berturut-turut 140,5 dan 116,41 . Rehabilitasi hutan mangrove dengan metode yang selama ini dilakukan telah mengubah struktur vegetasi hutan mangrove di Pulau Lombok yang juga dapat mempengaruhi fauna asosiasi dan ekosistem sekitar mangrove. Oleh karena itu, diperlukan perencanaan serta analisis terlebih dahulu terhadap lokasi tujuan rehabilitasi mangrove agar untuk terbentuknya hutan mangrove rehabilitasi yang lebih sesuai dengan biota asosiasi dan ekosistem sekitar yang telah ada sebelumnya.

Kata Kunci: Struktur Komunitas, Mangrove, Alami, Rehabilitasi

Abstract: Rehabilitation of mangrove vegetation was an effort in order to decrease the rate of mangrove ecosystem destruction. This research aimed to determine the vegetation structure and the community status of natural and rehabilitation mangrove forest at South Lombok seashore. This research held on March - June 2019 at two types of mangrove ecosystem such as natural ecosystem at pemongkong, East Lombok and rehabilitation ecosystem at Gerupuk bay, Central Lombok. Data collection used plotted transect method by placed a plot sized $10 \times 10 \mathrm{~m}$ alternately. There are 11 species of mangrove found which belong to 4 families such as Avicenniaceae (Avicennia alba, A. marina, A. lanata), Rhizophoraceae (Ceriops decandra, C. tagal, Rhizophora apiculata, $R . \quad$ mucronata, $R$. stylosa), Rubiaceae (Scyphiphora 
hydrophyllaceae) and Sonneratia (Sonneratia alba, S. casiolaris). Vegetation structure in these 2 location was different based on the composition each vegetation and it proportion. Natural mangrove forest in pemongkong dominated by Sonneratia alba with importance value reached 132,37, meanwhile the rehabilitation area of mangrove ecosystem Gerupuk dominated by Rhizophora apiculata with number of importance value reached 140,5. These differences drove the value of persent of similarity (PS) between these ecosystem only reached $10.41 \%$ which categorized as low similarity. Mostly of rehabilitation of mangrove ecosystem conducted cause the alteration of vegetation structure of mangrove in Lombok coastal and affect the mangrove associated fauna and ecosystems. In that case, it really important to analys the condition of mangrove rehabilitation plan location to determine the mangrove species to plant in order to formed a rehabilitiation of mangrove area which more compatible to its associated biota and ecosystems.

Keyword: Structure, Mangrove, Natural, Rehabilitation.

\section{Pendahuluan}

Hutan mangrove Indonesia merupakan luasan hutan mangrove tertinggi di dunia yaitu sekitar 4,25 juta Ha (Indriyanto, 2005; Noor et al., 2012; Kordi, 2014). Akan tetapi, laju kerusakan hutan mangrove di Indonesia juga sangat tinggi sehingga diperkirakan luas ekosistem mangrove telah berkurang 2,15 juta $\mathrm{Ha}$ dari total sebelumnya (Noor et al., 2012). Kerusakan hutan mangrove merupakan masalah serius yang kini sedang terjadi hampir di seluruh Indonesia, termasuk di pulau Lombok. Mujiono (2016) memenyatakan kawasan hutan mangrove Pulau Lombok yang masih dalam kondisi baik hanya sekitar 1.643 ha atau sekitar $49,7 \%$ dari total 3.305 ha kawasan hutan mangrove Pulau Lombok. Sebagai upaya mengurangi laju kerusakan hutan mangrove, maka dilakukannlah rehabilitasi ekosistem mangrove.

Rehabilitasi hutan mangrove di Indonesia sejauh ini hanya dilakukan dengan menggunakan satu jenis tumbuhan mangrove saja yaitu dari genus Rhizophora spp. (Anwar dan Mertha, 2017; Ahyadi et al., 2018) tanpa memperhatikan kondisi ekosistem yang di rehabilitasi dan zonasi tumbuhan mangrove yang sebelumnya ada. Secara alami, tumbuhan mangrove memiliki zonasi tertentu berdasarkan jenis tumbuhan yang cocok hidup di kondisi spesifik ekosistem mangrove (Indriyanto, 2005; Supriharyono, 2009; Noor et al., 2012; Alidrus, 2014; Kordi, 2012). Zonasi alami mangrove dari laut ke daratan secara umum terdiri atas zona Avicennia dan Sonneratia, zona Rhizophora dan Bruguiera, zona Lumnitzera, dan zona Nypa (Bengen, 2003; Indriani, 2008; Noor et al., 2012). Zonasi tumbuhan mangrove ini sangat mempengaruhi peranan mangrove baik secara fisik maupun peranan secara ekologis, terutama terhadap kelangsungan hidup biota asosiasi mangrove (Sani et al., 2019).
Rehabilitasi hutan mangrove yang hanya memanfaatkan satu jenis pohon saja dapat mengubah sistem zonasi alami yang telah berlangsung di ekosistem tersebut. Hal tersebut dapat ditunjukkan dengan memonitoring struktur vegetasi mangrove di kawasan yang telah dilakukan rehabilitasi (Wijaya dan Huda, 2018). Monitoring atau pemantauan kondisi ekosistem mangrove rehabilitasi merupakan salah satu upaya yang diperlukan untuk memastikan keberhasilan rehabilitasi hutan mangrove serta sebagai bahan evaluasi untuk melanjutkan upaya rehabilitasi yang telah dilakukan (Sani, 2019)

Keberhasilan upaya rehabilitasi yang dilakukan dapat dilihat dengan membandingkan antara kawasan mangrove hasil rehabilitasi dengan ekosistem mangrove yang telah ada secara alami terutama pada aspek biologisnya (Sani, 2019). Salah satu komponen yang dapat diamati adalah struktur vegetasi dari kedua tipe ekosistem mangrove tersebut. Secara alami, dua ekosistem mangrove yang memiliki kondisi lingkungan yang mirip akan memiliki struktur vegetasi mangrove yang tidak jauh berbeda pula (Noor et al., 2012; Alidrus, 2014). Oleh karena itu, sebagai pembanding dari kawasan rehabilitasi yang diamati, haruslah ekosistem mangrove yang berada dalam region yang sama.

Di pulau Lombok, kawaan yang masih memiliki kedua tipe ekosistem mangrove tersebut adalah kawasan pesisir selatan. Pesisir selatan pulau Lombok merupakan kawasan yang berhadapan langsung dengan samudera Hindia. Hal tersebut menyebabkan rehabilitasi kawasan mangrove di kawasan ini menjadi sangat penting dilakukan sebagai salah satu upaya untuk mencegah erosi karena gelombang dari arah samudera. Ekosistem mangrove rehabilitasi dengan jenis Rhizophora spp. dapat ditemukan di Teluk Gerupuk, Lombok Tengah, sedangkan ekosistem mangrove alami salah satunya 
berada di Desa Pemongkong, Lombok Timur. Monitoring struktur vegetasi mangrove di kedua ekosistem tersebut diharapkan dapat memberikan gambaran akan perubahan ekosistem mangrove yang terjadi akibat rehabilitasi yang dilakukan selama ini, sehingga diharapkan didapatkan cara yang lebih tepat untuk memperbaiki ekosistem mangrove yang rusak ke depannya.

\section{Bahan dan Metode}

\section{a. Pelaksanaan penelitian}

Penelitian ini dilaksanakan pada bulan Maret - Juni 2019 di 2 lokasi hutan mangrove yang termasuk kawasan pesisir selatan pulau Lombok yaitu hutan mangrove rehabilitasi Gerupuk, Lombok Tengah dan hutan mangrove alami Pemongkong, Lombok Timur.

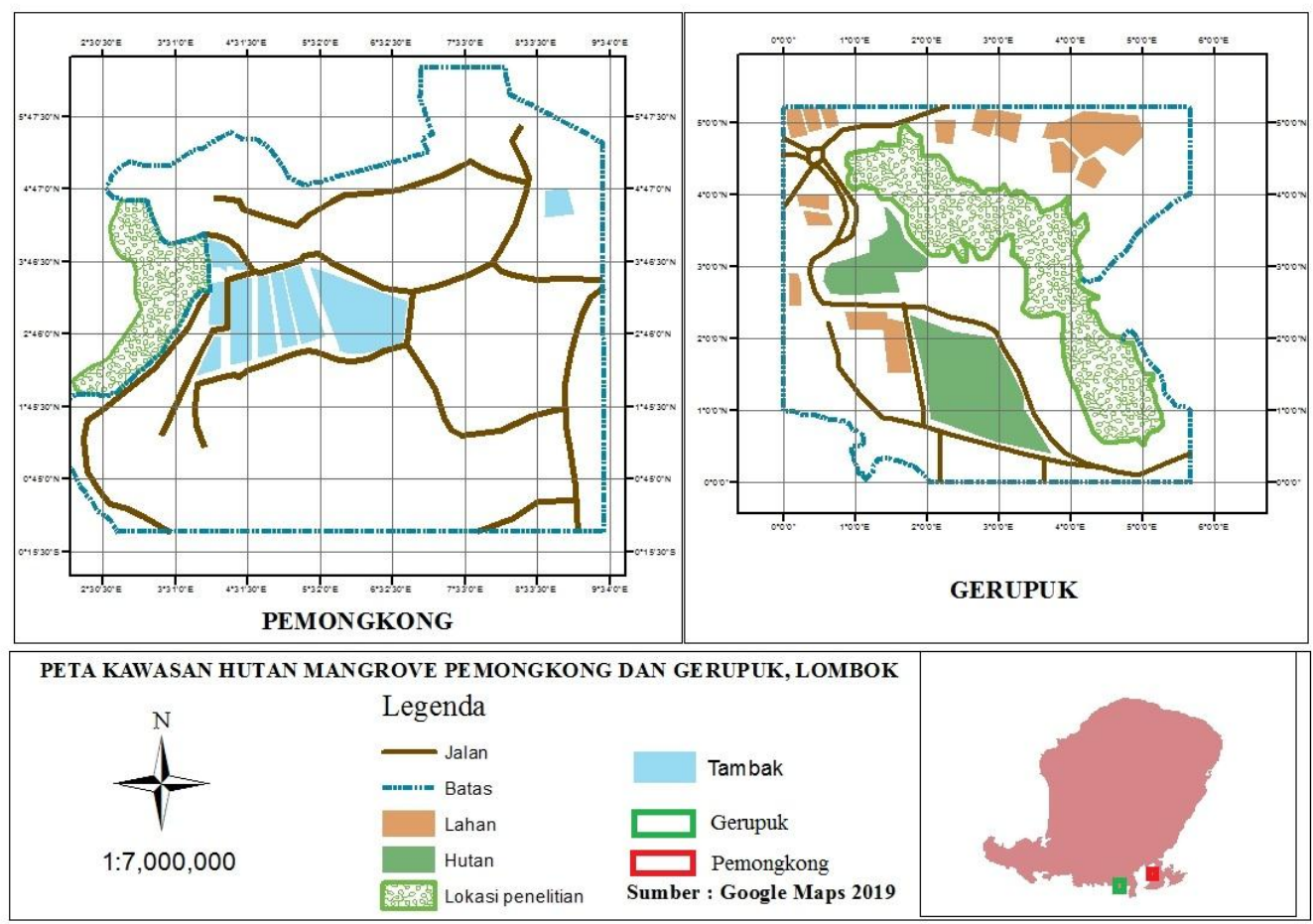

Gambar 1. Peta lokasi penelitian.

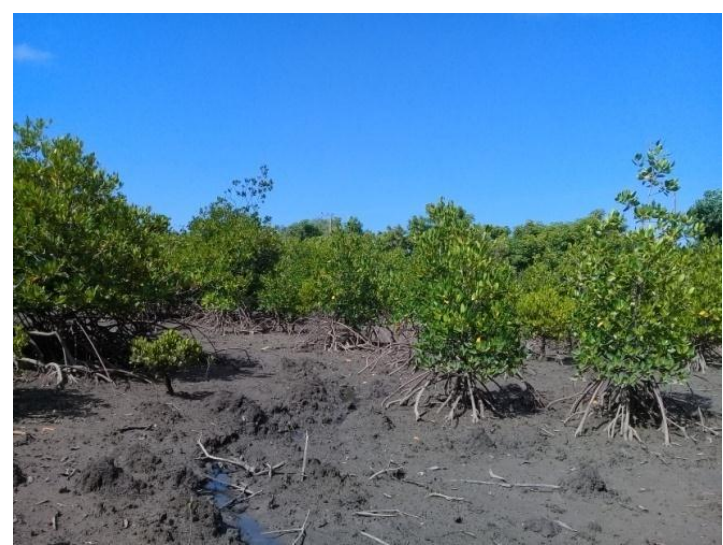

Gambar 2. Ekosistem mangrove rehabilitasi Teluk Gerupuk, Lombok Tengah

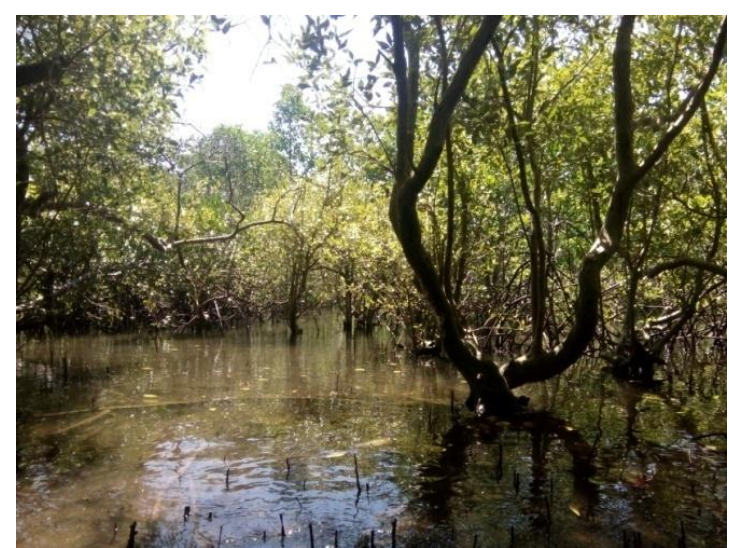

Gambar 3. Ekosistem mangrove alami Pemongkong, Lombok Timur 
b. Pengambilan data

Pengambilan data vegetasi mangrove dilakukan dengan menggunakan metode transek berpetak (plot). Garis transek ditempatkan secara sistematik dengan menarik transek lurus ke arah pantai dan memotong formasi mangrove. Pengambilan data ini bertujuan untuk mengetahui keanekaragaman jenis dan indeks nilai penting (INP) mangrove (Pradnyawati, 2018; Ahyadi et al, 2018).) Plot-plot pengamatan diletakkan berseling pada setiap transek. Pohon dengan diameter $(\geq 10 \mathrm{~cm})$ dibuat plot dengan ukuran $10 \times 10 \mathrm{~m}$, pancang (tinggi $>$ $1,5 \mathrm{~m}$-diameter batang $<10 \mathrm{~cm}$ ) dibuat plot dengan ukuran $5 \times 5 \mathrm{~m}$, dan semai dibuat plot dengan ukuran $2 \times 2 \mathrm{~m}$ (Ningsih, 2008). Selanjutnya dilakukan penghitungan jumlah individu dan pengukuran diameter batang setinggi dada (dbh) tiap jenis tumbuhan mangrove (Anwar dan Mertha, 2017).

\section{c. Analisis data}

Penentuan data vegetasi mangrove dapat ditentukan dengan mengetahui Indeks Nilai Penting (INP) suatu populasi mangrove dalam suatu komunitasINP merupakan akumulasi dari nilai kerapatan relative, frekuensi relatif, dan dominansi relative dari masingmasing spesies yang terdapat di suatu lokasi penelitian (Alidrus, 2014; Anwar dan Mertha, 2017; Dombois dan Ellenberg, 1974 dalam Pradnyawati, 2018). Selain itu, dilakukan penghitungan tingkat keanekaragaman jenis mangrove dengan menggunakan rumus indeks ShannonWienner, sedangkan tingkat similaritas kedua stasiun ditentukan dengan menggunakan Indeks Similaritas Sorensen (ISS) untuk menentukan persamaan kedua lokasi berdasarkan jenis mangrove yang ditemukan dan Persen Similaritas (PS) untuk menentukan persamaannya berdasarkan pada proporsi masing-masing spesies di lokasi tersebut (Smith and Smith, 2012; Molles Jr. and Sher, 2019; Aji dan Widyastuti, 2017).

\section{Hasil dan Pembahasan}

a. Keanekaragaman Jenis Tumbuhan Mangrove

Ekosistem mangrove rehabilitasi dengan jenis Rhizophora spp. dapat ditemukan di Teluk Gerupuk, Lombok Tengah, sedangkan ekosistem mangrove alami salah satunya berada di Desa Pemongkong, Lombok Timur. Berdasarkan hasil inventarisasi jenis mangrove yang dilakukan di hutan mangrove Teluk Gerupuk dan Desa Pemongkong ditemukan 11 spesies mangrove yang termasuk ke dalam 4 famili yaitu Sonneratiaceae (Sonneratia alba dan Sonneratia caseolaris), Avicenniaceae (Avicennia alba, Avicennia marina, dan Avicennia lanata), Rhizophoraceae (Rhizophora apiculata, Rhizophora mucronata, Rhizophora stylosa, Ceriops decandra, dan Ceriops tagal) dan Rubiaceae (Scyphiphora hydrophyllacea).

Sebanyak 8 spesies mangrove ditemukan di ekosistem mangrove alami Pemongkong, sedangkan di kawasan rehabilitasi ekosistem mangrove Gerupuk hanya ditemukan 7 spesies (Tabel 1). Jumlah tersebut jauh lebih sedikit dibandingkan dengan jumlah spesies yang ditemukan Ahyadi dan Suana (2018) di seluruh kawasan ekosistem mangrove Gerupuk yang menemukan 21 spesies mangrove. Perbedaan jumlah spesies ditemukan ini dikarenakan luasan area penelitian yang lebih kecil dan terbatas di kawasan mangrove rehabilitasi. Selain itu, rehabilitasi hutan mangrove di ekosistem mangrove Gerupuk hanya menggunakan jenis Rhizophora (Anwar dan Mertha, 2017; Ahyadi dan Suana, 2018) sehingga jenis-jenis mangrove yang tumbuh cenderung seragam dan keanekaragaman jenis yang ditemukan menjadi rendah. 
Tabel 1. Keanekaragaman jenis tumbuhan mangrove di ekosistem mangrove alami Pemongkong dan kawasan rehabilitasi mangrove Gerupuk.

\begin{tabular}{|c|c|c|c|c|}
\hline \multirow[b]{2}{*}{ No } & \multirow[b]{2}{*}{ Famili } & \multirow[b]{2}{*}{ Nama Jenis } & \multicolumn{2}{|c|}{ Lokasi Sebaran } \\
\hline & & & $\begin{array}{l}\text { Mangrove } \\
\text { Gerupuk }\end{array}$ & $\begin{array}{c}\text { Mangrove } \\
\text { Pemongkong }\end{array}$ \\
\hline \multicolumn{5}{|c|}{ Mangrove } \\
\hline \multirow[t]{3}{*}{1.} & \multirow[t]{3}{*}{ Avicenniaceae } & 1. Avicennia alba & - & $\sqrt{ }$ \\
\hline & & 2. Avicennia lanata & $\sqrt{ }$ & - \\
\hline & & 3. Avicennia marina & - & $\sqrt{ }$ \\
\hline \multirow[t]{5}{*}{2.} & \multirow[t]{4}{*}{ Rhizophoraceae } & 4. Ceriops decandra & $\sqrt{ }$ & $\sqrt{ }$ \\
\hline & & 5. Ceriops tagal & $\sqrt{ }$ & - \\
\hline & & Rhizophora apiculata & $\sqrt{ }$ & $\sqrt{ }$ \\
\hline & & Rhizophora mисronata & $\sqrt{ }$ & $\sqrt{ }$ \\
\hline & & 8. Rhizophora stylosa & $\sqrt{ }$ & - \\
\hline 3. & Rubiaceae & Scyphiphora hydrophyllaceae & - & $\sqrt{ }$ \\
\hline \multirow[t]{3}{*}{4.} & \multirow[t]{2}{*}{ Sonneratiaceae } & 10. Sonneratia alba & $\sqrt{ }$ & $\sqrt{ }$ \\
\hline & & . Sonneratia casiolaris & - & $\sqrt{ }$ \\
\hline & & Jumlah jenis & 7 & 8 \\
\hline
\end{tabular}

Keterangan: $(\sqrt{ })$ : ada; (-) tidak ada.

\section{b. Struktur Komunitas Mangrove}

Struktur komunitas terdiri atas jumlah spesies, kelimpahan relatif, serta jenis perbandingan spesies dalam suatu komunitas (Molles Jr. dan Sher, 2019). Struktur komunitas mangrove dalam penelitian ini ditunjukkan dengan menggunakan indeks nilai penting (INP). Nilai INP diperoleh dari akumulasi nilai kerapatan relatif, dominansi relatif, dan frekuensi relatif masing- masing spesies mangrove. INP menunjukkan seberapa penting suatu jenis tumbuhan terhadap ekosistemnya (Alidrus, 2014). Spesies mangrove yang memiliki INP tinggi berarti memiliki peranan yang sangat besar terhadap ekosistem mangrove habitatnya, begitupun sebaliknya jika INP suatu spesies kecil, maka keberadaanya tidak memberikan pengaruh yang terlalu besar terhadap ekosistem tersebut (Sidiyasa, 2007).

Diagram 1. Struktur vegetasi ekosistem mangrove alami dan rehabilitasi pada tingkat pertumbuhan pohon.

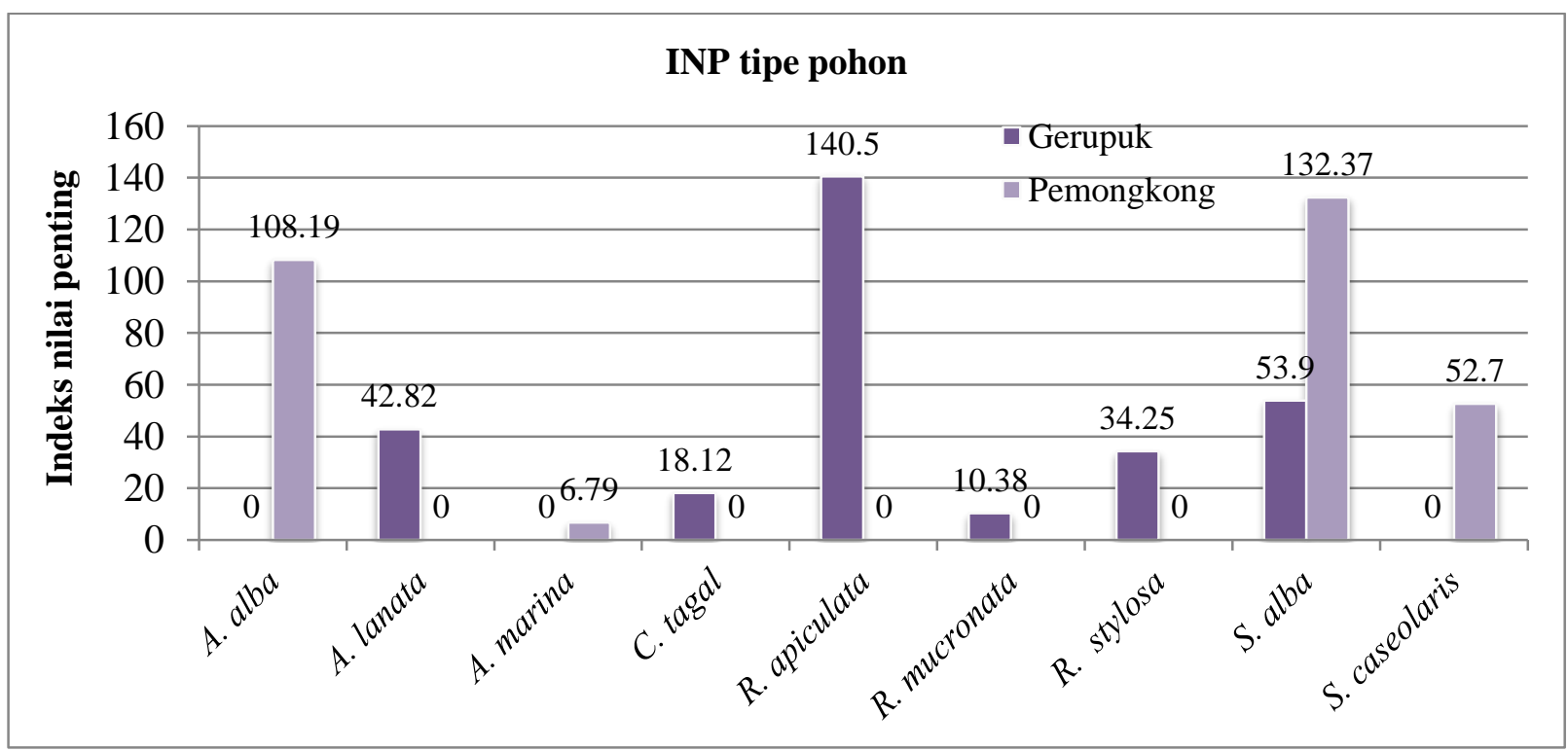


Diagram 2. Struktur vegetasi ekosistem mangrove alami dan rehabilitasi pada tingkat pertumbuhan pancang.

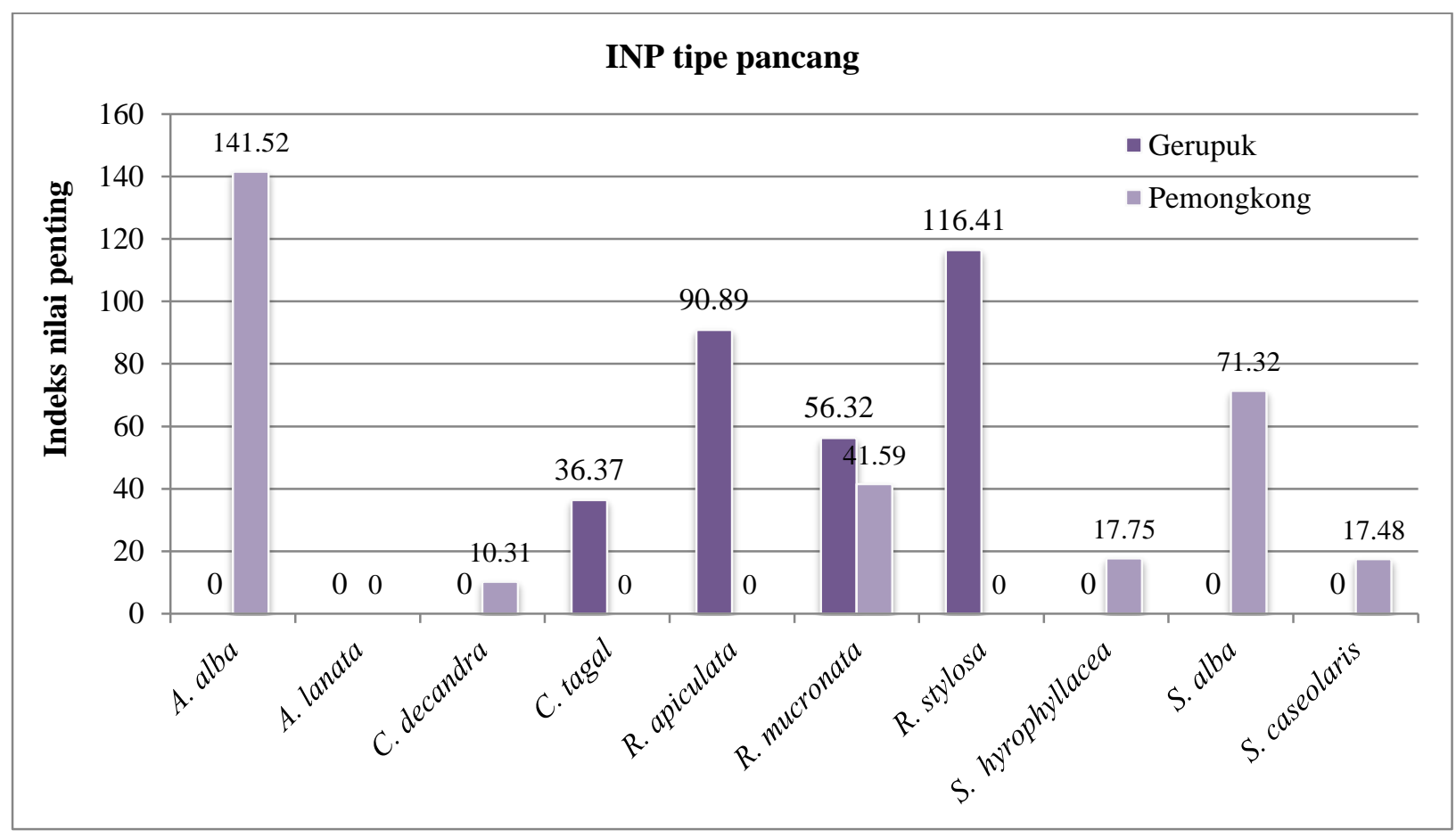

Berdasarkan hasil penelitian, vegetasi mangrove di ekosistem mangrove rehabilitasi Gerupuk dan ekosistem mangrove alami Pemongkong memiliki struktur yang jauh berbeda. Di Gerupuk, vegetasi dengan tingkat pertumbuhan pohon yang memiliki INP tertinggi adalah jenis $R$. apiculata dengan INP 140.5, sedangkan pada tipe pancang yaitu jenis $R$. stylosa dengan nilai penting 116.41. Tingginya INP dari genus Rhizophora disebabkan karena kawasan ini merupakan area rehabilitasi yang dilakukan menggunakan jenis tersebut (Anwar dan Mertha, 2017). Lebih lanjut Ahyadi dan Suana (2018) menyatakan bahwa hutan mangrove Gerupuk termasuk kawasan rehabilitasi dengan menggunakan jenis bakau (nama lokal Rhizophora).

Berbeda dengan kondisi hutan mangrove Gerupuk, struktur vegetasi hutan mangrove Pemongkong didominasi oleh jenis Sonneratia alba dan Avicennia alba pada tipe pohon dengan nilai penting masingmasing 132.37 dan 108.19, sedangkan INP tertinggi untuk tipe pancang adalah jenis $A$. alba dengan nilai penting yaitu 141.52. Kealamian ekosistem ini dapat dilihat pada heterogenitas baik jenis, ukuran, atau diameter batang pohon, maupun jarak antar pohon (Ahyadi et al, 2018). Jika dilihat dari ukuran diameter pohon (dbh) yang $S$. alba dan A. alba yan mencapai 50 $\mathrm{cm}$, diperkirakan keberadaan hutan mangrove ini telah berlangsung dalam kurun waktu yang sangat lama dan telah mencapai komunitas klimaks, yaitu komunitas yang telah mengalami suksesi dan tetap bertahan secara alami selama tidak ada gangguan yang berarti (Molles dan Sher, 2019).

Merujuk kepada diagram 1 dan 2, terlihat bahwa struktur vegetasi di ekosistem mangrove Teluk Gerupuk juga tersusun oleh jenis Ceriops tagal meskipun kawasan tersebut adalah hasil rehabilitasi dengan jenis Rhizophora. Keberadaan C. tagal menunjukkan bahwa secara alami jenis ini dapat tumbuh dengan mudah di kawasan tersebut. Hal tersebut dapat mengindikasikan bahwa $C$. tagal merupakan jenis yang sangat cocok hidup dengan kondisi lingkungan di Teluk Gerupuk.

Selain indeks nilai penting, indeks keanekaragaman merupakan parameter penting dalam suatu kajian vegetasi (Pradnyawati, 2018). Hidayatullah dan Eko (2014) menyatakan semakin tinggi nilai indeks keanekaragaman maka tingkat keragaman jenis pada wilayah tersebut juga semakin tinggi yang kemudian mendorong terjadinya kestabilan dalam suatu ekosistem (Molles dan Sher, 2019). Nilai indeks keanekaragaman $\left(H^{\prime}\right)$ beserta kerapatan mangrove pada masing-masing tingkat pertumbuhan di kedua lokasi penelitian dicantumkan dalam tabel 2. 
Tabel 2. Indeks keanekaragaman (H') dan kerapatan mangrove di ekosistem mangrove alami Pemongkong dan ekosistem mangrove rehabilitasi Gerupuk.

\begin{tabular}{|c|c|c|c|c|}
\hline \multirow{2}{*}{ No. } & \multirow{2}{*}{ Stasiun } & & \multicolumn{2}{|c|}{ Mangrove } \\
\hline & & & $\mathbf{H}^{\prime}$ & K (ind/Ha) \\
\hline \multirow{3}{*}{1.} & \multirow{3}{*}{ Pemongkong } & $\mathbf{S}$ & 1,746 & 1.096 \\
\hline & & $\mathbf{P a}$ & 1,493 & 117,3 \\
\hline & & Po & 1,065 & 62,3 \\
\hline \multirow{3}{*}{2.} & \multirow{3}{*}{ Gerupuk } & $\mathbf{S}$ & 1,084 & 2.025 \\
\hline & & $\mathbf{P a}$ & 1,224 & 488 \\
\hline & & Po & 1,720 & 39 \\
\hline
\end{tabular}

Indeks keanekaragaman (H') di ekosistem mangrove alami Pemongkong dan kawasan rehabilitasi ekosistem mangrove Gerupuk termasuk ke dalam kategori rendah - sedang sehingga kedua ekosistem mangrove tersebut tidak dapat dikatakan dalam keadaan stabil berdasarkan keanekaragaman jenis mangrovenya. Kerapatan mangrove pada masing-masing tipe pertumbuhan juga berbeda-beda. Berdasarkan tabel 2, terlihat bahwa ekosistem mangrove rehabilitasi Gerupuk memiliki kerapatan yang lebih tinggi dibandingkan dengan ekosistem mangrove alami Pemongkong. Terdapat beberapa faktor yang menyebabkan kerapatan yang tinggi di hutan mangrove rehabilitasi Gerupuk diantaranya adalah jarak tanam pohon mangrove saat rehabilitasi yang terlalu dekat dengan jarak sekitar $2 \mathrm{~m}$. Kerapatan pohon mangrove mempengaruhi intensitas cahaya yang masuk ke dasar hutan mangrove. Intensitas cahaya yang masuk kemudian berpengaruh pada suhu lingkungan dan keberlangsungan hidup alga dan fitoplankton di ekosistem mangrove (Poedjirahajoe, 2017).

Vegetasi dalam suatu ekosistem selalu mendapat pengaruh dari lingkungan. Karakteristik fisik dan kimia lingkungan kedua lokasi teramati tercantum dalam tabel 3. Secara keseluruhan, kedua ekosistem ini tidak memilik perbedaan yang terlalu signifikan pada faktor lingkungan tersebut, kecuali pada parameter jenis dan kedalaman substrat. Perbedaan jenis dan kedalaman substrat menyebabkan vegetasi dominan yang tumbuh pada berbagai tingkat pertumbuhan di kawasan tersebut menjadi berbeda pula. Rhizophora spp. sangat cocok hidup di kawasan dengan substrat berlumpur hingga lumpur berpasir, begitu pula dengan anggota famili Rhizophoraceae lainnya (Noor et al, 2012; Alidrus, 2014). Oleh karena itu kondisi substrat di ekosistem mangrove rehabilitasi Gerupuk cocok ditumbuhi oleh jenis ini. Selain itu untuk jenis Rhizophora, kemampuan adaptasi dan tingkat survival dalam terhadap kondisi lingkungan sangat tinggi sehingga jenis ini mudah hidup di setiap kawasan. Sistem perakaran tunggang membuat jenis ini mampu mengendapkan lumpur pada substrat yang ditumbuhi sehingga menyebabkan kawasan yang ditumbuhi jenis ini menjadi lebih lembek dan berlumpur (Ahyadi dan Suana, 2018).

Begitu pula dengan kondisi substrat ekosistem mangrove Pemongkong yang didominasi oleh tanah lempung hingga lumpur halus dengan kedalaman mencapai $30 \mathrm{~cm}$. kondisi tersebut cocok untuk pertumbuhan Sonneratia dan Avicennia yang memiliki perakaran longitudinal. Di kawasan ini juga terdapat titik dengan kondisi substrat berpasir dan berbatu yang ditumbuhi oleh Sonneratia. Menurut Noor et al (2012), Sonneratia juga dapat tumbuh di kawasan yang berpasir hingga berbatu sehingga kondisi tersebut masih memungkinkan Sonneratia untuk tumbuh dengan baik. Namun tidak halnya dengan jenis Rhizophora. Faktor inilah yang kemungkinan menyebabkan sedikit ditemukannya jenis Rhizophora di ekosistem mangrove alami Pemongkong.

Tabel 3. Karakteristik fisik dan kimia lingkungan ekosistem mangrove Pemongkong dan Gerupuk.

\begin{tabular}{|c|c|c|c|}
\hline No. & Parameter & Pemongkong & Gerupuk \\
\hline 1. & Tipe substrat & $\begin{array}{c}\text { tanah } \\
\text { lempung - } \\
\text { lumpur halus }\end{array}$ & $\begin{array}{c}\text { pasir } \\
\text { berlumpur - } \\
\text { lumpur } \\
\text { berpasir }\end{array}$ \\
\hline 2. & $\begin{array}{l}\text { Kedalaman } \\
\text { substrat }\end{array}$ & $10-35 \mathrm{~cm}$ & $2-10 \mathrm{~cm}$ \\
\hline 3. & Suhu substrat & $32-34{ }^{\circ} \mathrm{C}$ & $30-34{ }^{\circ} \mathrm{C}$ \\
\hline 4. & Suhu udara & $32-34{ }^{\circ} \mathrm{C}$ & $29-32{ }^{\circ} \mathrm{C}$ \\
\hline 5. & $\begin{array}{l}\text { Kelembaban } \\
\text { substrat saat } \\
\text { surut } \\
\text { maksimal }\end{array}$ & $\begin{array}{l}60-\text { selalu } \\
\text { tergenang }\end{array}$ & $\begin{array}{l}65-\text { selalu } \\
\text { tergenang }\end{array}$ \\
\hline 6. & $\begin{array}{l}\text { Kelembaban } \\
\text { udara }\end{array}$ & $61-74$ & $75-86$ \\
\hline 7. & pH substrat & $6.05-6.5$ & $6.4-6.5$ \\
\hline 8. & $\mathrm{pH}$ air & 8 & $7-8$ \\
\hline 9. & Salinitas & $20-24 \%$ & $22-30 \%$ \\
\hline
\end{tabular}

Indeks similiaritas Sorensen (ISS) dan presentase similiaritas (PS) merupakan dua komponen yang digunakan untuk mengukur tingkat persamaan antara dua ekosistem yang diamati (Smith dan Smith, 2012). Indeks similiaritas Sorensen (ISS) merupakan salah satu indeks yang digunakan untuk menghitung similiaritas antara dua area atau plot sampel berdasarkan komposisi spesiesnya. Adapun PS merupakan cara menghitung tingkat kesamaan antara dua area penelitian berdasarkan proporsi kelimpahan relatif dari spesies di komunitas yang dibandingkan (Smith dan Smith, 2012). 


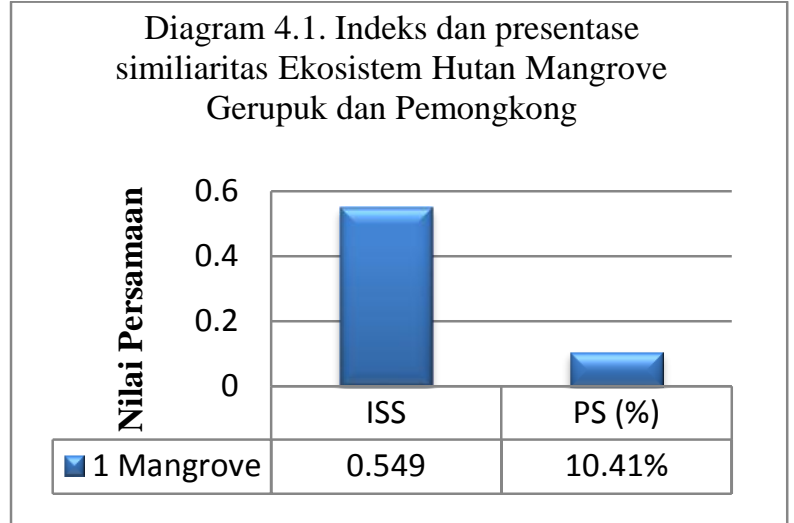

Keterangan; ISS: Indeks similiaritas Sorensen; PS: Presentase similiaritas

ISS vegetasi mangrove di lokasi penelitian bernilai 0.549 dan termasuk kategori tingkat similiaritas sedang karena hampir setengah dari total spesies yang ditemukan di lokasi penelitian satu ditemukan di lokasi penelitian lainnya. Sebanyak 4 dari 11 spesies tumbuhan mangrove ditemukan di kedua lokasi penelitian. Hal tersebut menjelaskan bahwa kedua lokasi penelitian memiliki persamaan jika dilihat dari jenis-jenis vegetasi yang ditemukan.

Perbedaan yang besar antara kedua lokasi terlihat pada presentase similiaritas (PS). Presentase similiaritas untuk vegetasi mangrove terhitung hanya $10.407 \%$ dan tergolong sangat rendah. Nilai PS memiliki rentang $0-$ $100 \%$ untuk menunjukkan similiaritas terendah ke tertinggi (Smith dan Smith, 2012). Rendahnya nilai PS menunjukkan perbedaan yang besar antara kedua lokasi penelitian dalam hal proporsi dari masing-masing spesies di dalam komunitasnya, baik untuk vegetasi mangrove maupun moluska asosiasinya. Perbedaan yang besar tersebut disebabkan karena proporsi dari masing-masing spesies yang ditemukan di salah satu lokasi penelitian sangat rendah dibandingkan dengan proporsi spesies yang sama di lokasi yang lain, serta adanya perbedaan jumlah jenis yang ditemukan di kedua lokasi penelitian.

Jika dilihat dari fauna asosiasi mangrove yang ditemukan di kedua lokasi penelitian, keanekaragaman jenis fauna di ekosistem mangrove alami Pemongkong jauh lebih tinggi dibandingkan dengan ekosistem rehabilitasi Gerupuk. Terdapat 34 spesies moluska asosiasi seperti Cherithidea spp., Littorina spp., dan sebagainya (Zvonareva et al., 2015; Mujiono, 2016; Yolanda, 2016) ditemukan diekosistem mangrove Pemongkong, sedangkan di ekosistem mangrove Gerupuk hanya ditemukan 17 spesies. Keanekaragaman jenis biota asosiasi dapat dijadikan sebagai bioindikator kondisi lingkungan mangrove yang baik untuk biotabiota mangrove.

\section{Kesimpulan}

Monitoring kondisi ekosistem mangrove rehabilitasi merupakan salah satu kegiatan yang perlu dilakukan dalam membandingkan struktur vegetasi mangrove rehabilitasi dengan alami. Ekosistem mangrove alami dan rehabilitasi peisisir Lombok Selatan memiliki perbedaan pada struktur vegetasi yang menutupi kedua tipe ekosistem tersebut. Perbedaannya yaittu tertinggi di Pemongkong untuk tipe pohon adalah Soneratia alba (INP 132.37), pancang dan semai Avicennia alba (INP 141.52 dan 55.34), sedangkan untuk kawasan Gerupuk, INP tertinggi untuk tipe pohon adalah jenis Rhizophora apiculata (INP 140.527) dan pada tipe pancang didominasi oleh $R$. stylosa dan Ceriops decandra((INP 116.41 dan 51.29).

\section{Ucapan Terima Kasih}

Peneliti menyampaikan terima kasih atas dukungan dari berbagai pihak yang telah membantu hingga terlaksanya penelitian ini. Ucapan terima kasih kepada bapak Wirya Arman dan keluarga yang telah memberikan berbagai bantuan dalam pelaksanaan penelitian, dosen pembimbing penelitian, serta pihak Universitas Mataram.

\section{Daftar Pustaka}

Ahyadi, H. \& I. W. Suana. (2018). Kajian Biodiversitas Mangrove dan Burung di The Mandalika, Indonesia Tourism Development Corporation (ITDC), Lombok.

Ahyadi, H., Sani. L. H., Riandinata, S. K. \& S. Hadi. (2018). The Condition of Mangrove Ecosystem Around Shipyard Project Site at Lembar Bay, Lombok. Dipresentasikan pada seminar $1^{\text {st }}$ International Conference and Workshop of Bioscience and Biotechnology, Mataram, 27 November 2018.

Aji, L. P. \& A. Widyastuti. (2017). Molluscs Diversity in Coastal Ecosystem of South Biak, Papua. Oseanologi dan Limnologi Di Indonesia, 2 (1), pp. $25-37$.

Al Idrus, Agil. (2014). Mangrove Gili Sulat Lombok Timur. Arga Puji Press, Mataram.

Anwar, H. \& Mertha, I. G. (2017). Komposisi Jenis Mangrove Di Teluk Gerupuk Kabupaten Lombok Tengah. Jurnal Sangkareang Mataram, 3 (2): 2531 . 
Budhiman, S., R. Dewanti, C. Kusmana \& N. Puspaningsih. (2001). Kerusakan Hutan Mangrove Di Pulau Lombok Menggunakan Data Landsat-TM dan Sistem Informasi Geografis (SIG), Warta LAPAN, 3 (4), pp. $200-210$.

Hidayatullah, M. \& Pujiono Eko (2014). Struktur dan Komposisi Jenis Hutan Mangrove Di Golo Sepang-Kecamatan Boleng Kabupaten Manggarai Barat, Bandung. Jurnal Penelitian Kehutanan Wallacea, 3: pp. 151-162.

Indriyanto (2006). Ekologi Hutan. Bumi Aksara, Jakarta. Kordi K., M. Ghufran H. (2012).Ekosistem Mangrove: Potensi, Fungsi, dan Pengelolaan, PT. Rineka Cipta, Jakarta

Molles Jr., Manuel C. \& A. A. Sher. (2019). Ecology: Concepts and Applications, 8th Edition. McGrawHill Education, New York.

Mujiono, N. (2016). Gastropoda Mangrove dari Pulau Lombok, Nusa Tenggara Barat. Oseanologi dan Limnologi di Indonesia, 1 (3), pp.39-50.

Ningsih S.S. (2008). Inventarisasi Mangrove Sebagai Bagian dari Upaya Pengelolaan Wilayah Pesisir Kabupaten Deli Serdang. Thesis, Universitas Sumatera Utara.

Noor, Y. R., M. Khazali \& I N. N. Suryadiputra. (2012). Panduan Pengenalan Mangrove di Indonesia. Wetland International, Bogor.

Poedjirahajoe, E., Marsono D. \& Wadhani FK. (2017). Penggunaan Principal Component Analyisis dalam Distribusi Spasial Vegetasi Mangrove di Pantai Utara Pemalang. Ilmu Kehutanan,11 : 2942 .

Pradnyawati, Putu (2018). Struktur dan Analisis Vegetasi Mangrove Di Teluk Ekas Kecamatan Jerowaru Kabupaten Lombok Timur. Skripsi. Program Studi Biologi Fakultas MIPA Universitas Mataram.

Sani, Laily Hunawatun (2019). Komposisi Moluska Asosiasi Mangrove Alami dan Rehabilitasi Pesisir Lombok Selatan. Skripsi. Program Studi Biologi Fakultas MIPA Universitas Mataram.

Sidiyasa, K. (2007). Vegetasi dan Keanekaragaman Tumbuhan di Sekitar Areal Tambang Batubara Daeng Setuju dan Tanah Putih Pulau Sebuku Kalimantan Selatan. Info Hutan, 4 : 111-121.
Smith, T. M. \& R. L. Smith. (2012). Element of Ecology 8th Edition. Pearson Education Inc., USA.

Sulastini, Dian (2012). Seri Buku Informasi dan Potensi Mangrove Taman Nasional Alas Purwo. Balai Taman Nasional Alas Purwo, Banyuwangi.

Sulistiyowati, H. (2009). Biodiversitas Mangrove di Cagar Alam Pulau Sempu. Saintek, 8 : 59-61.

Supriharyono (2009). Konservasi Ekosistem Sumber Daya Hayati di Wilayah Pesisir dan Laut Tropis, Pustaka Pelajar, Yogyakarta.

Wijaya, Nirmalasari Idha \& Muhammad Huda (2018). Monitoring Sebaran Vegetasi Mangrove yang Direhabilitasi Di Kawasan Ekowisata mangrove Wonorejo Surabaya. Jurnal Ilmu dan Teknologi Kelautan Tropis, 10 (3): pp. 747-755. DOI: http://dx.doi.org/10.29244/jitkt.v10i3.21271.

Yolanda, R., Asiah \& B. Dharma (2016). Mudwhelks (Gastropoda: Potamididae) in Mangrove Forest of Dedap, Padang Island, Kepulauan Meranti District, Riau Province, Indonesia. Journal of Entomology and Zoology Studies, 4 (2), pp. 155 161.

Zvonareva, S., Y. Kantor, X. Li \& T. Britayev (2015). Long-term Monitoring of Gastropoda (Mollusca) Fauna in Planted mangroves in Central Vietnam. Zoological Studies (DOI 10.1186/s40555-0150120-0), pp. 1 - 16. 